\title{
TREATMENT PETROLEUM OIL CONTAMINATED SOIL BY INOCULATION OF DIFFERENT BACTERIAL STRAINS
}

\author{
Pankaj Kumar Jain
}

Address (es): Pankaj Kumar Jain,

Indira Gandhi Centre for Human Ecology, Environmental and Population Studies, Department of Envirobnmental Science, University of Rajasthan, 302 004, Rajasthan, INDIA, +91-9414971602.

*Corresponding author: pankajbio2001@gmail.com

\section{ABSTRACT}

Petroleum oil contains a large number of poly cyclic hydrocarbons (PAH's) that are toxic to living beings. The complete degradation of petroleum oil required a population of microorganisms in the soil. In the present investigation petroleum oil contaminated soil samples were incubated with four bacterial strains (Mycobacterium sp., Pseudomonas aeruginosa, Alcaligenes faecalis and Enterobacter cloacae) to study the bioremediation efficacy. The soil samples were analyzed for soil reaction $(\mathrm{pH})$, soil moisture content, soil organic carbon (SOC), available phosphorus $(\mathrm{P})$, total petroleum hydrocarbon content (TPH), total bacterial count $(\mathrm{TBC})$ and total petroleum degrading bacteria at the interval of 0 days (initial), 2 weeks, 4 weeks, 6 weeks and 8 weeks prior and after treatment by bacteria. Values obtained reveals that there was a clear modulating effect of bacteria on above determinations. Maximum decrements in TPH (86\%), soil pH (18.2\%) and SOC (40\%) were recorded in Pseudomonas aeruginosa inoculated samples..

Keywords: Pseudomonas aeruginosa, pH, Total Bacterial Count (TBC), Soil Organic Carbon (SOC), Total Petroleum Hydrocarbon (TPH) content

\section{INTRODUCTION}

The world depends on petroleum oil. Vast amount is used, transported, processed and stored around the world. In 2016, the total world consumption of petroleum is over 98.21 million barrels per day (US Energy Information Administration, 2017). India is the World's 23rd largest producer of crude oil (36.942 MMT in 2015-16). The total number of refineries is 21 and has second rank after China in Asia and in 2016-17 total refining capacity is 230.066 MMTPA (Ministry of Petroleum and Natural Gas, 2017). With such a high consumption, oil spills are inevitable. Environmental pollution with petroleum and petrochemical products (diesel, petrol, kerosene etc.) has been recognized as one of the most important serious current problem (Lu et al., 2015; Pant et al., 2016; Cachada et al., 2018). Since the introduction of oil exploration, the environment has been heavily contaminated with hydrocarbon pollutants, which enters in the environment through several routes.

Exxon Valdez, known as the most notable oil spills at sea which spilled thousands of tones oil (Paine et. al., 1996; Albaiges et. al., 2006). These oil spills can cause severe damage to sea and shoreline organisms (Whitfield, 2003). Other most responsible for the contamination of soil and water are service stations, garages, scrap yards, waste treatment plants, sawmills, wood impregnation plants etc. Mechanic workshops generating thousand million gallons of waste engine oil annually and discharged carelessly into the environment (Adegodroye, 1997; Faboya, 1997), out of which only one liter is enough to contaminate one million gallons of freshwater (USEPA, 1996). Thereafter, several researches have been examined the fate of petroleum in various ecosystem (Boehm et al., 1995; Whittaker et al., 1999). These petroleum pollutants in the terrestrial and aquatic environments cause public health and socio-economic hazards (Adelowo and Oloke, 2002; Okerentugba and Ezeronye, 2003; Edewor et al., 2004).

The release of oil into the environment causes environmental anxiety and attracts the public awareness (Roling et al., 2002). Accidentally or deliberately releasing of oil into the environment, leads serious pollution problems (Thousand $\boldsymbol{e t}$ al., 1999). Even small release of petroleum oil into aquifers can lead to concentrations of dissolved hydrocarbons far in excess of regulatory limits (Spence et al., 2005). Huge disturbances of both the biotic and abiotic components of the ecosystem are created by such these pollutants (Mueller $\boldsymbol{e t}$ al., 1992) and carcinogenicity, immunotoxicity and neurotoxicity has proved by the some of these hydrocarbons (Hallier-Soulier et al., 1999; Das and Chandran, 2011).

Microbial biodegradation of pollutants has intensified in recent years as human strives to find sustainable ways to clean up contaminated environments (Diaz, 2008). Biodegradation of petroleum hydrocarbons by natural populations of microorganisms (bacteria, fungi algae etc.) represent one of the primary mechanism by which petroleum and other hydrocarbon pollutants are eliminated from the environment. The effects of environmental parameters viz.- temperature, $\mathrm{pH}$, concentration of hydrocarbon, bioavailability etc. on microbial degradation of hydrocarbons, the elucidation of metabolic pathways, genetic basis for hydrocarbon dissimilation by microorganisms and the effects of hydrocarbon contamination on microbial communities have been the areas of intense interest and the subjects of several reviews (Atlas, 1981; 1994). If there is no contamination in the area, the percentage of hydrocarbon degraders of all the microbial strain in the soil or water is quite low $(<1 \%)$, but after an oil spill, their level may increase 1000 fold (Atlas, 1981; Prince, 2005). These microorganisms can degrade a wide range of target constituents present in oily sludge (Eriksson et al., 1999; Barathi and Vasudevan, 2001; Mishra et al., 2001). So, the biodegradation of oil pollutants has been intensively studied either in controlled condition (Chaillan et al., 2006) or in open field experiments (Gogoi et al., 2003; Chaineau, et al., 2005).

Biodegradation of oil contaminated soils (which exploits the ability of microorganisms to degrade and/or detoxify organic contamination) has been established as one efficient, economic, versatile and environmentally sound treatment (Margesin and Schinner, 1997). Biodegradation of petroleum hydrocarbon pollutants and petrochemicals by bacteria have been extensively investigated (Obire and Nwaubeta, 2001; Ijah and Akpera, 2002; Okoh, 2002; Nweke and Okpowasili, 2003; Okerentugba and Ezeronye, 2003; Sanni and Ajisebutu, 2003; Oboirien et al., 2005; Ojumu et al., 2005).

A large number of bacteria for example Pseudomonas spp. (Kiyohara et al., 1992; Johnson et al., 1996; Pathak et al., 2008), Yokenella spp., Stenotrophomonas spp., Alcaligens spp., Roseomonas spp., Flavobacter spp., Corynebacterium spp., Streptococcus spp., Providencia spp., Sphingobacterium spp., Capnocytophaga spp., Moraxella spp., Bacillus spp. (Rusansky et al., 1987; Antai, 1990; Bhattacharya et al., 2003). Enterobacter spp., Escherichia spp. and Hafnia spp. ((Grant, 1967; Ijah., 1998; Diaz et al., 2001; Jain et al., 2010), Acinetobacter baumannii KSS1060 (Shiri et. al., 2015), Burkholderia xenovorans (Bhattacharya and Khare, 2017), Rhodobacter sphaeroides (Peng et al., 2018), Bacillus salmalaya strain 139SI (Dadrasnia et. al., 2016) have been reported in the literature for hydrocarbon degradation.

In the present study, four bacterial strains namely Mycobacterium sp., Pseudomonas aeruginosa, Entrobacter cloacae and Alcaligenes faecalis were studied for bioremediation of petroleum contaminated site.

\section{MATERIALS AND METHODS}

\section{Sample collection and preparation}

Sub surface oil contaminated soil samples were collected after removal of surface litter to a depth of about $5 \mathrm{~cm}$ in an approximately $2 \mathrm{~m}^{2}$ area from automobile workshops and near petrol pump stations of Mussorrie, India. These sites have a history of oil contamination of over 30 years. Soil samples were processed immediately upon arrival at laboratory. Dried sludge was passed 
through a $2 \mathrm{~mm}$ sieve and stored at $10^{\circ} \mathrm{C}$ for physico-chemical and microbiological characterization.

These soil samples were analyzed by soil reaction $(\mathrm{pH})$ (ISO 10390. 1994), soil moisture content (ISO 11465. 1993), soil organic carbon (SOC) (ISO 10694. 1995), available phosphorus ( $\mathrm{P}$ ) (Olsen and Cole, 1954), total petroleum hydrocarbon content (TPH), total bacterial count (TBC) and total petroleum degrading bacteria prior (0 days) and after 2 weeks, 4 weeks, 6 weeks and 8 weeks with bacterial strains of Mycobacterium sp., Pseudomonas aeruginosa, Alcaligenes faecalis and Enterobacter cloacae.

\section{Enumeration of total bacterial count (TBC)}

The mean total aerobic bacteria present in the samples at the beginning of the experiment (day 0) and at weekly intervals for each of the treatment options were estimated using spread plate method with nutrient agar as medium. A ten-fold dilution using physiological saline was prepared and $0.1 \mathrm{ml}$ of appropriate dilution was plated in duplicates and incubated for $18-24 \mathrm{~h}$ at $37^{\circ} \mathrm{C}$ temperature after which the colonies were counted.

\section{Enumeration of total petroleum degrading bacteria}

Aliquots $(0.1 \mathrm{ml})$ of appropriate dilutions of soil samples were plated on to modified mineral salts medium containing the following in g.L $\mathrm{L}^{-1}: \mathrm{NaCl}, 10.0$; $\mathrm{MgSO}_{4} .7 \mathrm{H}_{2} \mathrm{O}, 0.42 ; \mathrm{KCl}, 0.29 ; \mathrm{KH}_{2} \mathrm{PO}_{4}, 0.53 ; \mathrm{NH}_{4} \mathrm{NO}_{4}, 0.42$; agar, 15.0 and distilled water (Mills et al., 1978). The vapor phase transfer technique (Okpokwasili, 1988) was adopted, which employs the use of sterile filter paper soaked in crude oil, which served as the carbon and energy source. The soaked sterile filter papers were then aseptically placed onto covers of the inoculated inverted plates and incubated for 5 to 7 days at $37^{\circ} \mathrm{C}$ temperature. Average mean counts of colonies from duplicate plates were recorded and used for the calculation of colony forming units per gram (cfu/g) of soil.

\section{Measurement of crude oil utilization}

Residual crude oil was extracted from the soil samples using a modified method of Abu and Ogiji, 1996. Quantitative determination of the crude oil extracts was carried out as described by Udeme and Antai, 1988. A standard curve of absorbance $\left(\mathrm{A}_{520} \mathrm{~nm}\right)$ against varying concentrations of engine oil (1 to $\left.5 \%\right)$ in chloroform was drawn after taking readings from a Thermo Fischer scientific UV/VS spectrophotometer. The hydrocarbon concentrations were calculated from the standard curve after multiplying by the appropriate dilution factor.

\section{RESULTS AND DISCUSSION}

The contaminated soil samples were incubated with various strains of bacteria to study the bioremediation efficacy. The soil samples prior and after incubation were analyzed for soil reaction $(\mathrm{pH})$, soil moisture content, soil organic carbon (SOC), available phosphorus (P), total petroleum hydrocarbon content (TPH), total bacterial count (TBC) and total petroleum degrading bacteria. Gradual changes in $\mathrm{pH}$, soil moisture content, SOC, available $\mathrm{P}, \mathrm{TPH}, \mathrm{TBC}$ and total petroleum degrading bacteria in soil samples at different time intervals recorded. Table 1 represents the soil composition, physico-chemical properties and microbiological analysis of petroleum contaminated soil samples at 0 days. It indicates high TPH and SOC in soil samples. Total bacterial count (TBC) and total petroleum degrading bacteria were close to $10^{7}$ cells per gram dry soil and marginal difference was recorded between total bacterial count and total petroleum degrading bacteria.

A considerable decrement in soil $\mathrm{pH}$ value was recorded in all the treated soil samples after 8 weeks of incubation period. The maximum decline in $\mathrm{pH}$ was recorded in soil samples inoculated with bacterial strain of Pseudomonas aeruginosa (figure1). This decrement may be attributed to $\mathrm{CO}_{2}$ evolution as a result of microbial respiration and other enzymatic reactions. Similar reports have been put forward by Daylan et al., 1990. $\mathrm{pH}$ values major parameter to be taken in the account during major industrial bioremediation practices like land farming (USEPA, 2006). Besides neutral, $\mathrm{pH} \mathrm{6-8} \mathrm{has} \mathrm{also} \mathrm{been} \mathrm{reported} \mathrm{to} \mathrm{be}$ acceptable (USEPA, 2006). High pH values have been reported to be inhibitory to the majority of the microbial degradation processes. The optimal biodegradation activity at $\mathrm{pH} 7.4$ and a considerable inhibition at $\mathrm{pH} 8.5$ have been reported by Verstraete et al., 1975.
Table 1 Soil composition at the time of sample collection ( 0 week)

\begin{tabular}{llll}
\hline S. No. & Soil parameters & Unit & Quantity \\
\hline 1. & Sand & $\%$ & $38.07 \pm 2.2$ \\
\hline 2. & Slit & $\%$ & $37.02 \pm 1.8$ \\
\hline 3. & Clay & $\%$ & $25.05 \pm 1.2$ \\
\hline 4. & $\mathrm{pH}$ & - & $7.68 \pm 0.18$ \\
\hline 5. & Moisture & $\%$ & $18.86 \pm 1.1$ \\
\hline 6. & Organic carbon & $\%$ & $5.79 \pm 0.08$ \\
\hline 7. & Total Nitrogen & $\%$ & $0.05 \pm 0.02$ \\
\hline 8. & C/N Ratio & - & 115.8 \\
\hline 9. & Available P & $\mathrm{mg} / \mathrm{kg}$ & $1.8 \pm 0.1$ \\
\hline 10. & $\begin{array}{l}\text { Total petroleum } \\
\text { hydrocarbon (TPH) }\end{array}$ & $\mathrm{mg} / \mathrm{kg}$ & $13826 \pm 135$ \\
\hline 11. & $\begin{array}{l}\text { Total bacterial count } \\
\text { (TBC) }\end{array}$ & $\mathrm{CFU} / \mathrm{g}$ & $4.5 \times 10^{7}$ \\
\hline 12. & $\begin{array}{l}\text { Total Petroleum } \\
\text { degrading bacteria }\end{array}$ & $\mathrm{CFU} / \mathrm{g}$ & $1.3 \times 10^{7}$ \\
\hline
\end{tabular}

Value represent mean \pm SEM $(n=3)$.

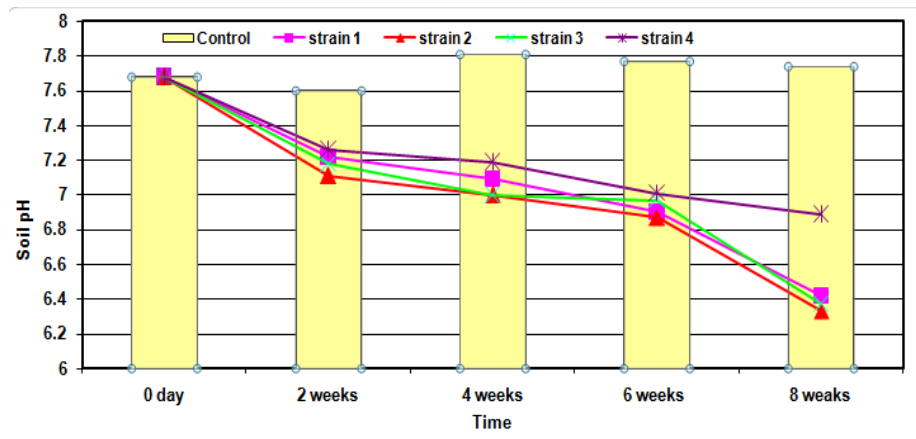

Figure 1 Soil reaction $(\mathrm{pH})$ in soil sample inoculated with different strains of hydrocarbon degrading bacteria

Variable soil moisture content was recorded in soil samples after 8-weeks incubation which was relatively higher in treated soil samples. In the present investigation, during remediation moisture content was dropped in control due to soil drying and evaporation of water. As the soil samples remediate through the introduction of microbes, moisture content was increased. The maximum moisture content was found in bacterial strain Pseudomonas aeruginosa inoculated soil sample where it was least in soil sample incubated with bacterial strain Alcaligenes faecalis. This might be due to the reduction of hydrophobic component of oil (Ghulam et al., 2008).

A significant reduction in soil organic carbon (SOC) content was recorded in soil samples inoculated with different bacterial strains. These data indicate that the organic carbon reduced with the time due to consumption of carbon. The maximum reduction was observed in soil samples inoculated with bacterial strain Pseudomonas aeruginosa (figure 2).

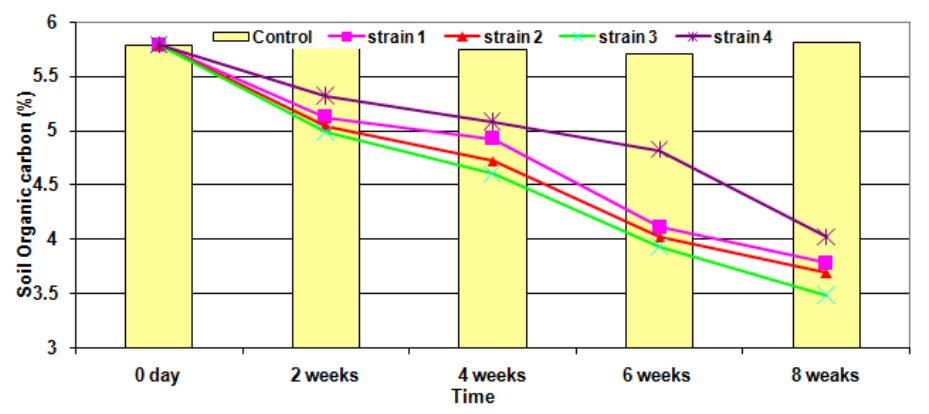

Figure 2 Soil organic carbon (SOC) in soil samples inoculated with different strains of hydrocarbon degrading bacteria

During biodegradations unlike organic carbon the available phosphorus (P) levels were also modulated during the bioremediation (figure 3 ). The available $\mathrm{P}$ increased from considerably during soil remediation. This increment in available phosphorous can be attributed to solubilization of soil phosphorus through microbial reactions. The increased partial pressure of $\mathrm{CO}_{2}$ generated from microbial respiration and other biological activities may be an important factor for solubilization of phosphorous. Therefore, increased level of available phosphorous was recorded. 


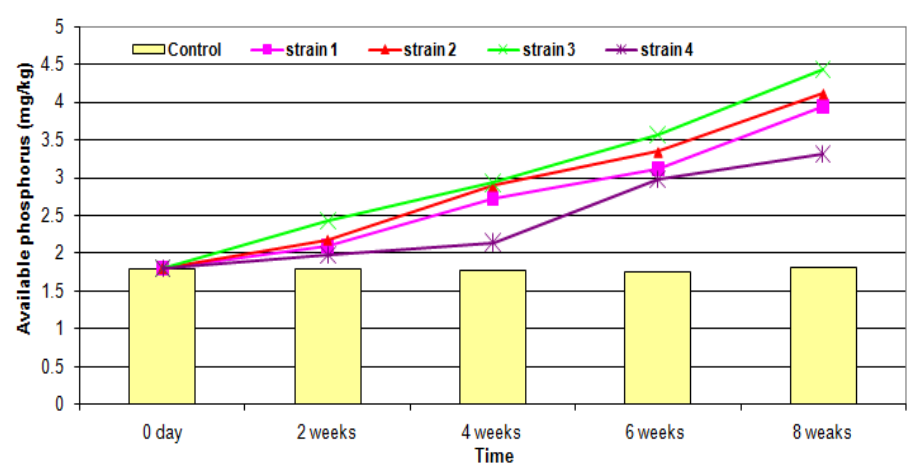

Figure 3 Available phosphorous in soil samples inoculated with different strains of hydrocarbon degrading bacteria

All the strains tested were capable to degrade total petroleum hydrocarbon (TPH). After eight weeks of incubation, the maximum TPH concentration was retained in soil samples inoculated with bacterial strain Alcaligenes faecalis. Data suggested that Enterobacter cloacae and Pseudomonas aeruginosa was most efficient and Alcaligenes faecalis was the slowest in the petroleum hydrocarbon degradation (figure 4). This was also paralleled by increment in number of total bacterial count (figure.5) and total petroleum degrading bacteria.

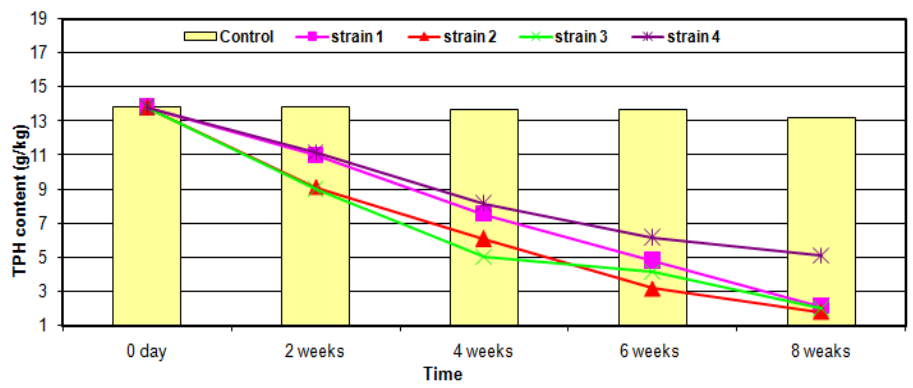

Figure 4 Total petroleum hydrocarbon content (TPH) in soil samples inoculated with different strains of hydrocarbon degrading bacteria

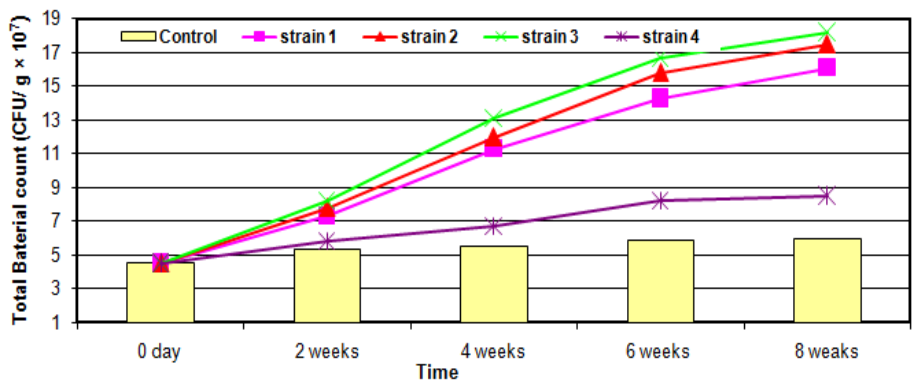

Figure 4 Total Bacterial Count (TBC) in soil samples inoculated with different strains of hydrocarbon degrading bacteria

In the present investigation, one soil sample inoculated with Mycobacterium. Degrading capacity of this bacterium has been widely supported in various reports (Cheung and Kinkle, 2001; Plohl et al., 2002). This bacterium showed $83 \%$ decrement of the TPH after 8 weeks incubation. Such kinetics for degradation of TPH has been intensively described by Panikov $\boldsymbol{e t}$ al., 2007. Similar bacterium was also isolated by Toledo et al., 2006 from waste oil. These data suggest that this bacterium can be utilized to remove the loads of contaminants from petroleum polluted sites.

The other soil sample was inoculated with Pseudomonas aeruginosa. This potential degrader of petroleum hydrocarbons has also been reported for its efficiency in bioremediation by several researchers (Emtiazi et al., 2005; Toledo et al., 2006; Adelowo et al., 2006; Madri and Lin, 2007; Pathak et al., 2008; Shokrollahzadeh et al., 2008; Tao Cheng et. al., 2017). The soil samples incubated with Pseudomonas aeruginosa established that this bacterium was more efficient in degradation of TPH as compared to other strains studied here. TPH degradation up to $86 \%$ was recorded in 8 -weeks incubation period clearly establishes the potential of this strain. The similar results were also put forward by Madri and Lin 2007. However, they achieved 90\% degradation of oil component. This difference in percentage degradation achieved by them and percentage degradation recorded in the present investigation may be attributed to the $\mathrm{pH}$ and temperature conditions.

In the present investigation, other soil sample inoculated with Enterobacter cloacae. This bacterium belongs to Enterobacteriaceae family and mainly regarded as inhabitant of animal gut (Diaz et al., 2001). The ability of this group to degrade high molecular weight PAH compounds appear to be an unusual feature, as this phenomenon is associated with typical soil bacteria. However, few reports indicated the utilization of aromatic compounds by Enterobacter (Ijah, 1998). Enterobacter inoculated sample exhibited that after 8 weeks $84 \%$ TPH contents were degraded. The similar results were observed Katsivela et al., 2003. They isolated two bacterial strains viz. Enterobacter sp. EK 3.1 and Enterobacter sp. EK 4 and demonstrated novel degradation capabilities for mixture of petroleum hydrocarbons. The Enterobacter sp. was observed to possess the unique capability of metabolizing PAH as well as the recalcitrant branched alkanes. Although there are several reports on bioremediation of high molecular weight $\mathrm{PAH}$, but research pertaining on biodegradation of these substances by Enteric bacteria are relatively rare (Kanaly and Harayama, 2000; Diaz et al., 2001).

One soil sample was inoculated with Alcaligenes faecalis. This bacterium has capacity to degrade $61 \%$ TPH after 8 weeks incubation period. Alcaligenes sp. described as Alcaligenes faecalis 212-2 was also isolated from waste crude oil by Toledo et al., 2006. They observed that fluorothene and phenantherene were effectively utilized by Alcaligenes faecalis 212-2, whereas, naphthalene was utilized by Bacillus subtilis, Alcaligenes faecalis 212-2 and Enterobacter species.

During the initial phase of remediation, low values of total bacterial count and total petroleum hydrocarbon degrading bacteria were observed. The possible reason was that the high concentration of petroleum hydrocarbons present in soil renders the toxicity which in turn may be detrimental to the soil microbes. The microbial population is directly affected by this lethal concentration. Similar results for bacterial counts have also been reported by Atlas (1981), Wang (1984), Bauda and Block (1985), Pettibone and Cooney (1988) and Odokuma and Dickson (2003). Further increase in duration of incubation period for hydrocarbon degradation resulted in reduction in number of bacteria in all the inoculated soil samples which may be attributed to reduction in the amount of available nutrients required for bacterial growth and altered physico-chemical conditions of soil.

The disappearance of TPH may be due to biodegradation by indigenous microorganism in soil, but also by physiochemical process like volatilization, photo-oxidation, absorption or by leaching (Northcott and Jones, 2000). However, due to absence of the light during these experiments, photo-oxidation cannot explain the loss of TPH. In contrast, biodegradation and volatilization certainly played a predominant role in the fate of low molecular weight TPH. The high degree of degradation observed in unfertilized mesocosms can be explained on the basis of these physico-chemical processes (Park et al., 1990).

The alkane fraction of oil was degraded faster than the aromatic fraction. The degree of degradation of n-alkanes shorter chains was higher than the n-alkanes longer chains. This was independent to initial level of contamination. These results are in agreement with the observation of Seklemova $\boldsymbol{e t}$ al., 2001. The degree of degradation of TPH was inversely proportional to the number of rings in the PAH (poly cyclic hydrocarbon) molecule. This observation is in consistency with previous studies on PAH degradation by Leblond et al., 2001. Hydrocarbons loss through natural processes decreased with time. However, biodegradation rates are low or negligible at concentration below a critical level (Allard and Neilson, 1997; Paton et al., 2003). This critical level may depend on the soil structure and on the composition of the contaminant. It has been suggested that bioremediation rate is not likely to be effective with extensively degraded oil (Bragg et al., 1994). Aged hydrocarbon residues were not bioavailable to metabolically competent microorganisms capable of degrading hydrocarbon (De Jonge et al., 1997; Eriksson et al., 2001; Paton et al., 2003).

Present study suggests that these strains possess optimal growth capacity for removing of hydrocarbons under the experimental conditions. However, utilization of TPH seems to be under the control of inducible systems and obviously a variety of factors can affect the ability of these microbes to degrade hydrocarbons in natural environment.

Acknowledgements: Author would like to thanks Director, Indira Gandhi Centre for Human Ecology Environmental and population studies, University of Rajasthan, Jaipur for his advice, guidance and technical review.

\section{REFERENCES}

ABU G.O. AND P.A. OGIJI, 1996. Initial test of a bioremediation scheme for the clean up of an oil polluted water body in a rural community in Nigeria. 
Bioresource Technology, 58: 7-12. https://doi.org/10.1016/S09608524(96)00080-6

ADEGODROYE, G., 1997. Environmental considerations in property design, urban development and renewal. In Akinjide O Ed. Dimensions problems in Nigeria. Friedrich Ebert Foundation. pp. 12-25.

ADELOWO, O.O. AND OLOKE J.K., 2002. Comparison of the emulsification and oil displacement profile of some biosurfactants. NISEB J. 23: 181-186.

ADELOWO, O.O., S.O. ALAGBE AND AYANDELE A.A., 2006. Timedependent stability of used engine oil degradation by cultures of Pseudomonas fragi and Achromobacter amogenes. Afr. J. Biotechnol. 5(24): 2476-2479.

ALBAIGES, J., B. MORALES-NIN AND F. VILAS, 2006. The Prestige oil spill: A scientific response. Mar. Pollut. Bull. 53: 205-207. https://doi.org/10.1016/j.marpolbul.2006.03.012

ALLARD, A. AND A. NEILSON, 1997. Bioremediation of organic waste sites: A critical review of microbiological aspects. Int. Environ. Eng. ASCE. 125: 2735 .

ANTAI, S.P., 1990. Biodegradation of Bonny light crude oil by Bacillus sp. and Pseudomonas spp. Waste Manag. 10: 61-64. https://doi.org/10.1016/0956053X(90)90070-2

ATLAS, R.M., 1981. Microbial degradation of petroleum hydrocarbons: An environmental perspective. Microbiol. Rev. 45: 180-209.

ATLAS, R.M., 1994. Hand book of microbiological media. L.C. Parks. CRC Press. pp. 175 .

BARATHI, S. AND N. VASUDEVAN, 2001. Utilization of petroleum hydrocarbons by Pseudomonas fluorescence isolated from a petroleum contaminated soil. Environ. Int. 26: 413-416. https://doi.org/10.1016/S01604120(01)00021-6

BAUDA, P. AND J. C. BLOCK, 1985. Cadmium biosorption and toxicity to laboratory grown bacteria. Environ. Technol. Let. 6: 445-454.

BHATTACHARYA, D., P.M. SARMA, S. KRISHNAN, S. MISHRA AND B. LAL, 2003. Evaluation of genetic diversity among Pseudomonas citronellolis stains isolated from oily sludge contaminated sites. Appl. Environ. Microbiol. 693: 1435-1441. https://doi.org/10.1128/AEM.69.3.1435-1441.2003

BHATTACHARYA, A., S.K. KHARE, 2017. Biodegradation of 4chlorobiphenyl by using induced cells and cell extract of Burkholderia xenovorans, Bioremediation Journal 21:3-4, 109-118. DOI: 10.1080/10889868.2017.1282940

BOEHM, P.D., G.S. DOUGLAS AND J.S. BROWN, 1995. Advanced chemical fingerprinting for oil spill identification and natural resource damage assessments. pp. 967-969. Proceedings, 1995 Oil Spill Conference. API, Washington, DC.

BRAGG, J. R., C. R. PRINCE, E. J. HARNER AND RONALD M. ATLAS, 1994. Effectiveness of bioremediation for the Exxon Valdez oil spill. Nature. 368: 413-418.

DADRASNIA A., MOHAMMED MAIKUDI USMAN, KELVIN SWEE CHUAN WEI, RITA DEVI, VELAPPAN HOSSEIN JAMALI, NOOSHIN MOHEBALI, SALMAHISMAIL, 2016. Native soil bacterial isolate in Malaysia exhibit promising supplements on degrading organic pollutants. Process Safety and Environmental Protection. 100: 264-271.

DALYAN, U., H. HARDER, T. HR. HOPNE, 1990. Hydrocarbon biodegradation in sediments and soils: A systematic examination of physical and chemical conditions. Part II pH values. Wissensachft and Technik

DAS N. AND P. CHANDRAN, 2011. Microbial degradation of petroleum hydrocarbon contaminants: an overview. Biotechnol. Res. Int. 2011:941810. https://doi.org/10.4061/2011/941810

DE JONGE, H., J.I. FREIJER, J.M. VERSTRATENM, J.WESTERVELD AND F.W.M. VANDER WIELEN, 1997. Relation between bioavailability and fuel oil hydrocarbon composition in contaminated soil. Enviorn. Sci. Technol. 31: 771775 .

DIAZ, E., 2008. Microbial Biodegradation: Genomics and Molecular Biology, $1^{s t}$ Ed., Caister Academic Press.

DIAZ, E., A. FERNANDEZ, M.A. PRIETO AND J.L. GARCIA, 2001. Bioremediation of aromatic compounds by Escherichia coli. Microbiol. Mol. Biol. Rev. 65: 523-569. https://doi.org/10.1128/MMBR.65.4.523-569.2001 EDEWOR, T.I., O.O. ADELOWO AND T.J. AFOLABI, 2004. Preliminary studies into the biological activities of a broad spectrum disinfectant formulated from used engine oil. Poll. Res. 234: 581-586.

EMTIAZI, G., H.S. HAKARAMI, I. NAHVI AND S.H. MIRDAMADIAN, 2005. Utilization of petroleum hydrocarbons by Pseudomonas spp. and transformed Escherichia coli. Afr. J. Biotechnol. 4(2): 172-176.

ERIKSSON M., J.A. KA AND W.W. MOH, 2001. Effects of low temperature and freeze - than cycles on hydrocarbon biodegradation in Arctic tundra soil. Appl. Enviorn. Microbiol. 67: 5107-5112.

ERIKSSON, M., G. DALHAMMER AND A.K. BORG-KARLSON, 1999. Aerobic degradation of a hydrocarbon mixture in natural uncontaminated potting soil by indigenous microorganisms at $20^{\circ} \mathrm{C}$ and $6^{\circ} \mathrm{C}$. Appl. Microbiol. Biotechnol. 51: 532-535.

FABOYA, O.O.P., 1997. Industrial pollution and waste management in Akinjide O. Ed. Dimensions of environmental problems in Nigeria, Friedrich Ebert Foundation. pp. 12-25.

GHULAM, S., M. AFZAL, F. ANWAR, R. TAHSEEN AND Z.M. KHALID, 2008. Biodegradation of kerosene in soil by a mixed bacterial culture under different nutrient conditions. Intl. Biodeter. Biodegrad. 61: 161-166.

GOGOI, B.K., N.N. DUTTA, GASWAMIP AND T.R. MOHAN, 2003. A case study of bioremediation of petroleum hydrocarbon contaminated soil at a crude oil spill site. Adv. Environ. Res. 7: 767-782.

GRANT, D.J.W., 1967. Kinetic aspects of the growth of Klebsiella aerogenes with some benzenoid carbon sources. J. Gen. Microbiol. 46: 213-224.

HALLIER-SOULIER, S., V. DUCROCQ, N. MAZURE AND N. TRUFFAUT, 1999. Detection and quantification of degradative genes in soils contaminated by toluene. FEMS Microb. Ecol. 20: 121-133.

CACHADA, A., T. ROCHA-SANTOS, A.C. DUARTE, 2018. Soil and Pollution: An Introduction to the Main Issues. In Soil Pollution, Elsevier. pp 128.

CHAILLAN, F., C.H. CHAINEAU, V. POINT, A. SAILOT AND J. OUDOT, 2006. Factors inhibiting bioremediation of soil contaminated with weathered oils and drill cuttings. Environ. Pollut. 144 (1): 255-265.

CHAINEAU, C.H., G. ROUGEUX, C. YEPREMIAN AND J. OUDOT, 2005. Effects of nutrient concentration on the biodegradation of crude oil and associated microbial populations in the soil. Soil. Biol. Biochem. 37: 1490-1497. CHEUNG, P.Y. AND B.K. KINKLE, 2001. Mycobacterium diversity and pyerene mineralization in petroleum contaminated soils. Appl. Environ. Microbiol. 67: 2222-2229.

CHUKWUMA, M. C., ESHETT, E. T., ONWEREMADU, E. U., M. A. OKON, 2010. ZINC availability in relation to selected soil properties in a crude oil polluted eutrictropofluvent. International Journal of Environmental Science and Technology. 7 (2): 261-270.

IJAH, J.J. AND M. AKPERA, 2002. Effect of salinity of crude oil utilization by marine yeast isolates. J. Pure Appl. Sci. 3(2): 216-222.

IJAH, J.J., 1998. Studies on relative capabilities of bacterial and yeast isolates from tropical soil in degrading crude oil. Waste Manag. 18: 293-299.

ISO 10390, 1994. Soil Quality - Determination of pH. International Organization for Standardization.Geneva, Switzerland. $5 \mathrm{p}$. (available at www.iso.ch)

ISO 10694, 1995. Soil Quality - Determination of organic and total carbon after dry combustion (elementary analysis). International Organization for Standardization. Geneva, Switzerland. 7p. (available at www.iso.ch)

ISO 11465, 1993. Soil Quality - Determination of dry matter and water content on a mass basis -Gravimetric method. International Organization for Standardization. Geneva, Switzerland. 3 p. (available at www.iso.ch)

JAIN, PANKAJ KUMAR, VIJAI KUMAR GUPTA, HARDIK PATHAK, MADAN LOWRY AND D. P. JAROLI, 2010. CHARACTERIZATION OF $2 \mathrm{~T}$ ENGINE OIL DEGRADING INDIGENOUS BACTERIA, COLLECTED FROM HIGH ALTITUDE MUSSOORIE REGION OF INDIA. World Journal of Microbiology and Biotechnology, 26:1419-1426. https://doi.org/10.1007/s11274-010-0316-8

JOHNSON, K., S. ANDERSON AND C.S. JACOBSON, 1996. Phenotypic and genotypic characterization of phenanthrene - degrading fluorescent Pseudomonas biovars. Appl. Environ. Microbiol. 62: 3818-3825.

KANALY, A.R. AND S. HARAYAMA, 2000. Biodegradation of high molecular weight polycyclic aromatic hydrocarbon by bacteria. J. bacteriol. 182(8): 2059-2067.

KATSIVELA, E., E.R.B. MOORE AND N. KALOGERAKIS, 2003. Biodegradation of aliphatic and aromatic hydrocarbon; specificity among bacteria isolated refinery waste sludge. Water Air and Soil Pollut.. 3: 103-115.

KIYOHARA, H., N. TAKIZAWA AND K. NAGAO, 1992. Natural distribution of bacteria metabolizing many kinds of polycyclic aromatic hydrocarbons. J. Ferment. Bioeng. 74: 49-51.

LEBLOND, J.D., T.W. SCHULTZ AND G.S. SAYLER, 2001. Observation on the preferential biodegradation of selected components of polycyclic aromatic hydrocarbon mixtures. Chemosh. 42: 333-343.

LU, Y., S. SONG, R. WANG, Z. LIU, J., A. J. MENG SWEETMAN, A. JENKINS, R.C. FERRIER, H. LI, W. LUO, 2015. Impacts of soil and water pollution on food safety and health risks in China. Environment international 77:5-15

MADRI, T. AND J. LIN, 2007. Isolation and characterization of engine oil degrading indigenous microorganisms in Kwazulu - Natal, South Africa, Afr. J. Biotechnol. 6(1): 23-27.

MARGESIN, R. AND F. SCHINNER, 1997. Bioremediation of diesel oil 
contaminated alpine soils at low temperatures. Appl. Microbiol. Biotechnol. 47: $462-468$.

MILLS A.L., BREUIL C. AND R.R. COLWELL, 1978. Enumeration of petroleum degrading marine and estuarine microorganisms by the most probable number method, Can. J. microbiol. 24: 552-557.

MINISTRY OF PETROLEUM AND NATURAL GAS, INDIA, 2016-17. Annual Report, pp12-13

MISHRA, S., J. JYOT, R.C. KUHAD AND B. LAL, 2001. Evaluation of inoculum addition to stimulate in-situ bioremediation of oily-sludge contamination soil. Appl. Environ. Microbiol. 674: 1675-1681.

MUELLER, J.G., S.M. RESNICK, M.E. SHELTON AND P.H. PRITCHARD, 1992. Effect of inoculation on the biodegradation of weathered Prudhoe bay crude oil. J. Indst. Microb. 10: 95-102.

NORTHCOTT, G.L. AND K.C. JONES, 2000. Experimental approaches and analytical techniques for determine organic compound bond residues in soil and sediment. Enviorn. Pollut. 108: 19-43.

NWEKE, C.O. AND G.C. OKPOWASILI, 2003. Drilling fluid base oil biodegradation potential of a soil Staphylococcus species. Afr. J. Biotechnol. 2(9): 293-295.

OBIRE, O. AND O. NWAUBETA, 2001. Bio-degradation of refined petroleum hydrocarbon in Soil. JASEM. 5(1): 43-46.

ODOKUMA, L.O. AND A.A. DICKSON, 2003. Bioremediation of a crude oil polluted tropical fain forest. Global J. Environ. Sci. 2(1): 29-40.

OJUMU, T.V., O.O. BELLO, J.A. SONIBARE AND B.O. SOLOMON, 2005.

Evaluation of microbial systems for bioremediation of petroleum refinery effluents in Nigeria. Afr. J. Biotechnol. 4(1): 31-35.

OKERENTUGBA, P.O. AND O.U. EZERONYE, 2003. Petroleum degrading potentials of single and mixed microbial cultures isolated from rivers and refinery effluents in Nigeria. Afr. J. Biotechnol. 2(9): 293-295.

OKOH, A.L. , 2002. Assessment of the potentials of some bacterial isolates for application in the bioremediation of petroleum hydrocarbon polluted soil. Ph.D. thesis, Obafemi Awolowo University, lle-lfe, Nigeria.

OKPOKWASILI G.C. AND S.C. AMANCHUKWU, 1988. Petroleum hydrocarbon degradation by candida spp. Environ. Int. 14: 243-247.

OLSEN, S.R. AND C.V. COLE, 1954. V.S. Dept. Agric. Circ. pp.939.

PAINE, R., J. RUESINK, A. SUN, E. SOULANILLE, M. WONHAM, C. HARLEY, D. BRUMBAUGH AND D. SECORD, 1996. TROUBLE on oiled waters: Lessons from the Exxon Valdez oil spill. Annu. Rev. Ecol. Syst. 27: 197235.

PANIKOV, N.S., M.V. SIZOVA, D. ROS, C. CHRISTODOULATOS, W. BALAS AND S. NICOLICH, 2007. Biodegradation kinetics of the nitramine explosive CL-20 in Soil and microbial cultures. Biodegrad. 18(3): 317-332.

PANT, G., A. BHARADWAJ, N. WAHI, N. NEHRA, M. GUPTA, A.K.

BHATIA, 2016. Bioremediation: An Eco-friendly Approach for Treating Pesticides. Advances in Bioresearch 7:200-206.

PARK, K.S., R.C. SIMS, R.R. DUPONT, W.J. DOUCETTE AND J.E. MATHEWS, 1990. Fate of PAH compounds in two soil types: Influence of volatilization, abiotics loss and biological activity. Environ. Toxicol. Chem. 9: 187-195.

PATHAK, H., PANKAJ K. JAIN, D.P. JAROLI AND M. LOWRY, 2008.

Degradation of phenanthrene and anthracene by Pseudomonas strain, isolated from coastal area. Bioremed. J. 12(2): 111-116.

https://doi.org/10.1080/10889860802060485

PATON, G.I., C.O. IROEGBU AND J.J.C. DAWSON, 2003. Microbial characterization of a diesel contaminated beach site. Mar. Pollut. Bull. 46: 903917.

PENG, W., X. LI, J. SONG, W. JIANG, Y. LIU ， W. FAN, 2018.

Bioremediation of cadmium- and zinc-contaminated soil using

Rhodobacter sphaeroides. Chemosphere 197:33-41. doi: 10.1016

PETTIBONE, G.W. AND J.J. COONEY, 1988. Toxicity of methyltins to microbial populations in esturine sediments. J. Indust. Microbiol. 2: 373-378.

PLOHL K., H. LESKOVSEK AND M. BRICELJ, 2002. Biological degradation of motor oil in water. Acta Chim. Slor. 49: 279-289.

PRINCE, R., 2005. The microbiology of marine oil spill bioremediation. In: Ollivier, B., M. Magot, Editors. Petroleum microbiology. ASM Press, Washington D.C. USA.

ROLING, W.F.M., M.G. MILNER, D.M. JONES, K. LEE, F. DANIEL, R.J.P. SWANNELL AND I.M. HEAD, 2002. Robust hydrocarbon degradation and dynamics of bacterial communities during nutrient - enhanced oil spill bioremediation. Appl. Environ. Microbiol. 6811: 5537-5548.

RUSANSKY, S., R. AVIGAD, S. MICHAELI AND D.L. GUTNICK, 1987. Involvement of a plasmid in growth on and dispersion of crude oil by Acinetobacter calcoaceticus RA 57. Appl. Environ. Microbiol. 53: 1918-1923. SANNI, G.O. AND S.O. AJISEBUTU, 2003. Biodegradation of escravos light crude oil by some species of soil bacteria. Sci. Focus. 4: 87-95.
SEKLEMOVA, E.A. PAVLOVA AND K. KOVACHEVA, 2001. Biostimulation based bioremediation of diesel fuel: Field demonstration. Biodegrad. 12: 311-316.

SHIRI Z., R. K. KERMANSHAHI, M. R. SOUDI AND D. FARAJZADEH, 2015. Isolation and characterization of an n-hexadecane degrading Acinetobacter baumannii KSS1060 from a petrochemical wastewater treatment plant. Int. J. Environ. Sci. Technol. 12:455-464. 10.1007/s13762-014-0702-0 SHOKROLLAHZADEH, S., F. AZIZMOHSENI, F. GOLMOHAMMAD, H. SHOKOUHI AND F. K. GHIGHAT, 2008. Biodegradation potential and bacterial diversity of a petrochemical waster water treatment plant in Iran. Bioresour. Technol. 27(12): 34. https://doi.org/10.1016/j.biortech.2007.12.034 SPENCE, J.M., S.H. BOTTRELL, S.F. THORNTON, H.H. RICHNOW AND K.H. SPENCE, 2005. Hydrochemical and isotopic effects associated with petroleum fuel biodegradation pathways in a chalk aquifer. J. Contam. Hydrol. 79: 67-88.

TAO CHENG, JIBEI LIANG, JING HE, XINGCUI HU, ZHIWEI GE AND JIANHUA LIU, 2017. A novel rhamnolipid-producing Pseudomonas aeruginosa ZS1 isolate derived from petroleum sludge suitable for bioremediation. AMB Expr. 7:120.

THOUSAND, G., P. BAUDA, J. OUDOT, G. KIRSCH, C. SUTTON AND J.F. VIDALIE, 1999. Laboratory evaluation of crude oil biodegradation with commercial or natural microbial inocula. Can. J. Microb. 452: 106-115.

TOLEDO, F.L., C. CALVO, B. RODELAS AND J. GONZALEZ - LOPEZ, 2006. Selection and identification of bacteria isolated from waste crude oil with polycyclic aromatic hydrocarbons removal capacities. Sys. Appl. Microbiol. 29: 244. https://doi.org/10.1016/j.syapm.2005.09.003

UDEME J AND S.P. ANTAI, 1988. Biodegradation and mineralization of crude oil bacteria. Nig. J. Biotechnol. 5: 79.

US ENERGY INFORMATION ADMINISTRATION, SHORT-TERM ENERGY OUTLOOK DATA BROWSER, November 7, 2017.

USEPA (UNITED STATES ENVIRONMENTAL PROTECTION AGENCY), 1996. Recycling used oil: what can you do? Cooperation extension services ENRI. 317: 1-2.

USEPA (UNITED STATES ENVIRONMENTAL PROTECTION AGENCY), 2006. Land farming. http //www.epa.gov/oust/cat/landfarm. Htm

VERSTRAETE, W., R. VANLOOCKE, R. DEBORGER AND A VERLINDNE, 1975. Modeling of the breakdown and the mobilization of hydrocarbons in unsaturated soil layers. In J.M. 72. Sharpley and A.M. Kalpan (Ed.). Proceedings of $3^{\text {rd }}$ international biodegradation symposium. Applied science publishers ltd. London. pp.99-112.

WANG, W., 1984. Time response of Nitrobacter to toxicity. Enviorn. Inter. 10: 21-26.

WHITFIELD, J., 2003. How to clean a beach. Nature. 422: 464-466.

WHITTAKER, M., S. J. T. POLLARD AND G. RISDEN, 1999. The fate of heavy oil wastes in soil microcosms II: A performance assessment of source correlation indices. The Sci Total Environ. 226 (1, 2): 23-34. 